\title{
DEFENCE SPENDING and POLITICAL BUSINESS CYCLES IN TURKEY
}

\author{
Assist. Prof. Dr. Şennur SEZGİN, Pamukkale University Faculty of Economics and \\ Administrative Sciences, sennurs@pau.edu.tr
}

\begin{abstract}
The allocation and distribution of government resources is a political process by it is nature. Considerable amount of government spending goes to defence expenditure in Turkey. So, is defence spending affected from political business cycle? To answer this question, this study analyses relationship between political business cycle and total and disaggregate defence spending using regression analyses. This study find that there is no trace of political business cycle over defence spending in Turkey. Furthermore, this study indicate that military coup and increasing of terrorist incidents are cause an increase on defence expenditure.
\end{abstract}

Key Words: Political business cycle, Defence spending, Turkey,

\section{INTRODUCTION}

The political business cycle (PBC) literature has developed in the last three decades and links between politics and economics in several ways. According to PBC theory, country macroeconomic condition result of government policies and the state of the economy has affected voting behavior. Therefore, in democratic society governments would try to improve the economy before election in order to enhance re-election chances. Implications of the theories are searched in many countries (especially developed countries). Although many more studies about developed countries, there are a few studies in developing countries.

The allocation and distribution of government resources is a political process by it is nature. Turkey defence spending shows some important characteristics and considerable amount of government spending goes to defence expenditure in Turkey. Therefore, the relationship between defence spending and political business cycle is particularly important, since Turkey has allocated considerably percentage of resources to defence spending for along time. Besides, how 
political development affected this expenditure is also important. Recently, defense literature also focus on to incorporate voter behaviors into military expenditure models. Therefore, these study focus on political business cycle and defense spending in Turkey, especially in the 1958-2008 period.

PBC literature developed four types of model of PBC. These are: Opportunistic, rational opportunistic, partisan and rational partisan model. These study focus on opportunistic political business cycle. Partisan PBC's will not examine in this paper. Because partisan model of political business cycle are not relevant in the Turkish context. Political parties have different ideology from each other. Left wing parties more concern diminishing of the employment, while right wing parties priorities are reduction of inflation. But these priorities can not feet into Turkish condition. Because there are no clear definition of ideology which is based on specific economic policy. Furthermore, Partisan PBC models have usually seen two party system countries. It is not possible to separate political parties economy policies in Turkey. Sometimes left parties priorities can be inflation or unemployment can be come more important than inflation for right parties. Morever, Sayan and Berument (1997) study can not find any significant evidence of partisan PBC's in Turkey. For this reason, this study examines the validity of PBC within the Turkish context and it's relation to defense spending.

Our study differed from previous studies on three ways. First, there are a lot of studies testing the PBC hypothesis for developed countries, but there is a little studies for developing countries. This paper aims to fill this gap in the literature. In fact, our study was one of the first empirical studies to discuss political business cycles and defense spending relations in Turkey. Previous study did not consider military spending as a depended variable. Our study take military expenditure as a dependent variable and growth, population, number of terrorist incidents and election time is independent variable. Secondly, we used a large data set which covers from 1958 to 2008 and used important economic policy instrument and indicators. Third, in many previous studies, total military spending is just taken into analyze. But our study beside total military spending, disaggregate namely equipment and non-equipment military spending will also consider.

This study organize as follows. Political business cycle models and country application will be given section two. Following section will elaborated history of Turkish election. Turkish defence expenditure development will be given section four. Fifth section devoted data, model and empirical analysis. In last section some conclusion driven.

\section{POLITICAL BUSINESS CYCLE}

The term "political business cycle" refers to any influence that politicians may have on the economy. This definition may be too broadening. If we define more specifically, political business cycle refers incumbent government deliberately stimulate the economy in order to improve their re-election 
chances. There isn't one model to compromise PBC: literature has developed four different type of PBC to determine the existence of PBC's, These models are: Opportunistic political business cycle, rational opportunistic political business cycle, partisan political business cycle, rational partisan political business cycle.

Opportunistic PBC model was developed by Nordhaus (1975) suggests that incumbent government try to maximize only their probability of re-election, or probability of "survival" in office. Accordingly, incumbent governments create a seemingly strong economy before the elections with decreasing unemployment and increasing growth rates of the economy and inflation. After the election it applies opposite economy policy.(Asutay, 2004; 2). Nordhaus (1975) original model is based on the following assumption: (Alesina, Cohen and Roubini (1991), Alesina ve Roubini (1992), Alesina and other; 1997, s.20)

1. The economy can be described by an "expectation-augmented" Phillips curve.

2. voters have adaptive expectations

3. politicians are identical. They only care about holding office, and they do not have "partisan objectives".

4. politicians control a policy instrument which directly effects aggregate demand. That means inflation can be controlled directly by policy makers.

5. voters are naive and retrospective: this means they assess the incumbent government according to positive high growth, low employment and low inflation; they heavily relay on past observation. They do not understand the economic model (the Phillips curve) that relates inflation and unemployment.

6. election time is exogenously fixed.

Based on these assumption, Nordhaus model have following empirical implications. (Lee; 1997;8)

- $\quad$ every incumbent government adapt to the same policy: that means before each election economy is expand in order to take advantage of short-run Phillips curve.

- As a result of this expansion, inflation is increased near election time.

- After the election inflation is decreased because of post-electoral economic recession.

Therefore, under those assumptions, different economic variables at different level generate economic cycles according to electoral time, so this cycles cause of macroeconomic instability. Although PBC cause of macroeconomic instability, some of researcher, including Tufte (1978), point out that PBC may have beneficial effects in society. Since government 
redistribute resources more equally before elections than other times. ( Bravo and Silvestre, 2000, s.6)

Nordhaus (1975) model tested a lot of researcher. Some of result support to this model, some of them don't. Nordhaus tested his model and he find moderate support for his model. He tested for existence of the PBC in 9 developed countries for annual data on unemployment rate from 1947 to 1972. In his study, Nordhaus model's prediction that unemployment will rise during the first half of an incumbency (post election period) and will fall during the second half of an incumbency (pre-election period). This prediction was supported from Germany, New Zealand and U.S. However Australia, Canada, Japan and the United Kingdom did not show any effect. For France and Sweden unemployment cycle show very weak effects. Mac Rae (1977) developed Nordhaus model by using dynamic inflationunemployment relation in U.S between 1957-1972. According to his model if voters are myopic a dynamic trade-off between inflation - unemployment will lead to stable business cycle. But voters vote strategically, vote-loss minimizing behavior will lead to social optimum. (Mac Rae, 1977; 262). Some other more studies that support opportunistic PBC. (Paldam, 1979, Paldam 1983, Soh 1986, Alesina Cohen and Roubini 1991, Alesina, Cohen and Roubini 1997, Eren 1988, Spanakos 2001, Schultz 1995, Hallerberg and others 2001, Thames 1991, Treisman and Gimpelson 2001, Veiga 2002, Leetouwer and Maier 2002, Derm 2002)

On the other hand there some studies which are does not support to PBC. These studies are as follows: Andrikopoulos and others, 2004, Akcoraoglu and Yurdakul, 2004; Golden and Poterba 1980, Serletis and Afxentiou, 1998.

But Nordhaus model is not based upon rational behavior. Because, Phillips Curve has adaptive expectations and voters are myopic. Within this framework opportunistic PBC criticized many others researchers. Among them Rogoff ve Sibert (1988), Rogoff (1990), Persson ve Tabellini (1990). According to them, all incumbent government are opportunistic but their competence level is different from each other. Before election they know their competence level, but voters don't know. There is an asymmetry of information between voters and government. Therefore, before election government manipulating economic policy variables in order to seem the more competent. According to model more competent means government who can perform the higher quantity of public goods/services with same amount of public money. Result of the opportunistic behavior, public expenditure are rise or taxes rates are reduce before election in order to give idea that incumbent government is competent. (Veiga, 2002;3)

Rational opportunistic model also tested some researcher among them Richards (1986) analyzed ABD Federal Rezerv Bank between 1940-1984. $\mathrm{He}$ found that Rezerv bank may cause of PBC until 1975 to creating unanticipated money. After 1975 political cycles disappear in ABD. Another 
study focus on less develop countries. Block and his colleague examine 44 African countries with panel econometric data. They conclude that inflation and senioraj dramatically rise after election, and also budget deficit and public expenditure increase election years.

Partisan political business cycle was initiated by Hibbs (1977) which is based on idea of politicians are ideological. So they represent the interests of different pressure groups and, when are office follow policies that are favorable to their supporting groups. Usually left wing parties perform expansionary policies in order to reduce unemployment while right-wing parties pursue post-election contraction in order to reduce inflation. Therefore systematic and permanent partisan cycle occur when differ political party come into power. (Serletis, 1998; 29)

More recent literature started by Alesina (1987) combine partisan choice into a rational expectation model with wage and price rigidities. This theory called rational partisan theory. It stress policy uncertainty which is arising from electoral uncertainty interacts with rational expectation. Under the rational expectation real variables only influenced by unexpected inflation. But election results always include uncertainty, so that each election has policy shocks with temporary real effects. (Alesina et.all, 1997; 46)

Partisan and rational partisan political business cycle theories also tested. Among them Alesina and Sach (1988), Ellis and Thoma (1995), Vaubel (1997), Abdel-Rahman (1997), Carlsen and Pedersen (1999), Blomberg and Hess (2003).

\section{HISTORY OF TURKISH ELECTION}

Turkish Republic was established in 1923 and it's strategically located between Asia and Europe. Until 1946 election one party system was dominated which is called the Republican People's Party (RPP-Cumhuriyet Halk Partisi). In 1946, RPP split into two parties. The opposition party represent landed interest which is named the Democrat Party (DP). From this time Turkish election system become multi-party democracy. In this period Turkey become member of NATO in 1952. Turkish election history can be analyses in three part. First part occur between 1946-1960, second part between 1960-1980 and last one is from 1980 to 2007. In this first period election occurred in1946, 1950,1954, 1957. It could be say that this years is Democrat Party (DP) years and it ended Military intervention in 1960. Main economic characteristic of this period is agriculture led growth with a outward-oriented economic development.

Second period started with military intervention and witness the other two military backed government in 1970s and 1980s. This years was witnessed the competition between the left of center RPP and the right of center Justice Party (JP). JP was dominated from 1963 election to march 12, 1971 military 
coup. The 1973 and 1977 election was won by the RPP under the lider of Bülent Ecevit (Kalaycıoğlu,1997:2). This second period of Turkish political life can be describe as one dominant party (RPP or JP) and a few small parties coalitions years. But following a military ultimatum in 1971, political life change dramatically with the emergence of two new parties: the pro-Islamic National Order Party (NOP) and the ultra-nationalist National Action Party (NAP) (Tessler and Altınoglu,2004:23).

This second period compromise 1960-1980 and covers a number of important political and economic events. Economy characterized as import substitution development strategy within higher protection in domestic market. Military intervention, the Cyprus war took in 1974, Petroleum shocks happened in 1974 and 1979, left and right fight occurred in this period. Political base assassinations become daily affair from 1977. The 1977 election did not solve this chaos. US embargo, rising oil price did not help to country problem and economic situation give a signal of deep recession.

Usually Turkish political life analyze according to "center-periphery" division. Center represent modernist elites which are support RPP. Periphery is traditional group which is closed to DP ( JP after 1960 ). At least until 1980s these two parties successfully appeal to voters in the electoral contest, and majority of Turkish voters vote for these two parties (Mardin, 1986:128)

Third period covers between 1980 -2008. and there have been a number of important political and economic events. In 1980, again the military took over the governt in order to prevent from civil strife. The blame two major parties, not to cooperate for country favour. When military get to power, new constitution prepared and all political parties forbidden to enter elections. (until 1987 election) (Dodd,1992:23). Under this condition, election made in 1983. Motherland party (MP) captured majority of the seat in parliament under the leader of Turgut Özal who was dominated Turkish political life until 1990's. This years Turkish economy change rapidly. Structural adjustment and stabilization program was implemented on January 24, 1980 . This program aims at switches. Turkey's development strategy shifted from inward-oriented import substitution policy previous two decades to an outward oriented export promotion strategy. First of all, foreign trade regime was liberalized and export growth policies were adopted in 1983. This strategy was quiet successful. Until 1988 GDP was rise average $\% 5,8$ every year and did not show any sign of depression (Ertuğrul and Selçuk).

Motherland Party govern to Turkey until 1991 election without any coalition. This term witness the ethnic terrorism and rising "Islamic fundamentalism". From this time fragmentation and polarization re-emerged between Turkish electorate because of rapid social mobilization, mass rural migration, cultural cleavages, religions preference and older generation of politicians allowed to participated to election (Kalaycıoğlu,1997:4). 
In 1991 election, although True Path Party gain the \%27 of vote, it was not enough one party government. So True Path Party establish coalition government. In this coalition period, Turkish economy experience big economic recession. Early election decision made result of this economic crisis.

In 1994 early election, Turkish voters support decline from centre right and centre left parties. They prefer to Islamic party which is welfare party (WP) (new form of NOP) and nationalist party National Action Party (NAP).Result of 1994 election, WP was dominant party which is get \% 21,4 of votes and established a coalition with TPP. This coalition seen as a threat of democracy and WP leader forced to resign from prime minister. After this resignation new coalition cabinet and minority government installed.

In 1999 election centre right parties such as motherland party and true path party loses their influence on voter. Democratic Left Part which is centre left gain the \% 22,9 votes and second party was extreme right the National Action Party. In this period Turkish economy faced to economic crisis in 1999 and February 2001. East Asia and Russian crisis, big earthquake İzmit and Düzce was badly affected Turkish economy. Under this economic situation coalition government adopted the stabilization program. Bad economic situation lead to early election. November 2002 election brought important change in Turkish political life. Voters punish the most of old parties, only two parties gain the seat in the parliament. All other parties stay under the $\% 10$ national threshold. The Justice and Development Party win \%34 of votes and Republican people party gain the $\% 19$ of vote. This political structure saved by 2007 election exception of one more party (National Movement Part (MHP)) able to join the parliament. The post-1980 period call neo-liberal era. Economy policy based on liberalization and outward-oriented economic development strategy.

\section{TURKISH DEFENCE SPENDING}

Turkey is one of the largest countries in terms of population over 70 million inhabitants. It is a member of NATO (North Atlantic Treaty Organisation) and the OECD (Organisation for Economic Development and Co-operation), and it has relatively powerful military forces. Although economically, Turkey has a relatively low level of economic development compared with Western industrialised countries and a per capita national income in 2009 of about $\$ 10.000$, Turkish armed forces ranked seventh in the world and it is the largest armed force in NATO Europe. This means, Turkey allocates a significant part of its resources for defence. Sezgin (1998) indicated the growth rate of military expenditure and growth rate of GNP for Turkey between 1950 to 1994. They are an average of $6.2 \%$ and $5.4 \%$ per annum, respectively. Furthermore, he calculate defence burden of Turkish economy in same period as a percentage of military expenditure in the GNP which is average of $4.7 \%$ per annum, and 
share of military expenditure in the central government budget which is $21.7 \%$ per annum. Moreover, Turkey is also one of the leading arms importing countries in the world.Although Turkey's defence burden is one of the highest in NATO over the years, defence spending began to decrease after 2003 and according to SIPRI estimation, defence spending of Turkey occurred TL. 20,585 million (current prices), amounting to $2.1 \%$ of GDP in 2008, like similar to EU $(2.17 \%)$ and NATO average.

Defense spending can be affected several factor. GDP, population, allies, enemies of country are important determinants of military spending. Although Turkish defence spending has a substantial affect on the Turkish economy, the determinants of Turkish defence spending have not been extensively researched. Brauer (2002) indicates that determinant of Turkish defence spending is not clear. There is a few studies about this subject. Sezgin and Yıldırım (2002) study. found that Turkish defence spending is determined by NATO's defence spending, Greece's defence spending and some security considerations in short term. This means Turkish defence spending effect by allies and enemies in shortrun. However Greek defence spending does not have any significant effect on Turkish defence spending in the long run. On the other hand, Kollias and Paleologou (2003) find similar result for Greece. According to their study, Greek defence spending is strongly and positevly influenced by Turkish defence spending as well as NATO's spending. Morever, their study was tested domestic political colour effects and they find that it have positevly effected defence expenditure.

Karagöl and Turhan (2008) investigate relationship between external debt, defence spending and political business cycle in Turkey for 1960-2002. They used defence expenditure and political business cycle variable as a independent variable and external debt is dependent variable in their model. They find that there is no sign of oppurtinustic political business cycle over defence expenditure but it is influenced political ideology of government more than electoral effects. Right wing parties do more government spending than left wing parties, including defence expenditure. Furthermore, they conclude that defence expenditure continuos to increase in the post-election period.

Zuk and Woodbury (1986) analyses electoral cycle and defence spending relations by using time series approach of Box-Jenkins and Box-Tiao. They applied three types of election variables namely incumbent presidential, fouryear presidential and two year congressional and five kinds of defence spending variables namely total, personnel, procurement, operational and maintenanceThey do not find straightforward connettion between national election and five kinds of defence spending. In other words, macroeconomic policy instruments may not systematically used to win the presidential or congress election. According to them importants of defence expenditure is not just limited for election. As they state that "if it exists, could be less important or more complicated than once thought" 
Deroven and Heo (2000) analyses the relationship between defense spending and domestic politics in U.S.A period of 1953-1992 combining the PBC and the referendum approaches. The referendum model assume that approval rating are important for shaping government policies. They tested both PBC and approval rating to asses whether political manipulation of the defense spending have happened in U.S.A. They used pooled time-series analyses which defense prime contract awards (PCA) is defendant variable, unemployment, war involment, electoral cycles, presidential approval rating are independent variable. They found that rise of unemployment and re-election time lead to increases in PCA. The decline of presidential approval also brings an increase of PCA. According to their finding presidents can not used public resources just election time, he used this resources during to his administration.

\section{EMPIRICAL ANALYSIS}

Defence spending have considerable percentage in the public expenditure and this spending take attention from politician especially election time. Is this case for Turkey? Is Turkish politicians systematically manipulate defence spending to winning election. To answer this question, Turkish elections and some economic variables will be analyzed framework of below model.

\subsection{The Data and Model}

We use total annual defence expenditures for 1950-2008, disagreagete data which is occurred equipment and non-equipment for 1975-2008. Defence expenditure data are taken from various issues of NATO Review. Population, GDP and election data are obtain from TURKSTAT (Turkish Statistical Institute), Terrorism data is gattered from GTD (Global Terrorism Data) START University of Maryland.

The model constructed as follow:

$$
\begin{aligned}
& m e=\text { cons }+y+\text { pop }+ \text { cyp }+ \text { coup }+ \text { terror }+ \text { elec }+u_{t} \\
& \text { neme }=\text { cons }+y+\text { pop }+ \text { cyp }+ \text { coup }+ \text { terror }+ \text { elec }+u_{t} \\
& \text { eme }=\text { cons }+y+\text { pop }+ \text { cyp }+ \text { coup }+ \text { terror }+ \text { elec }+u_{t}
\end{aligned}
$$

Where

me: growth rate of real defence expenditure of Turkey

neme: growth rate of real non-equipment defence expenditure 
eme: growth rate of real defence equipment expenditure

$y$. growth rate of gross national product

pop: growth rate of population

cyp: Impulse dummy variable for years $1974-1975$ to absorb shock change in defence spending due to war between Turkey and Cyprus.

coup: dummy variable for military coup in Turkey. The variable takes value of 1 for the years 1969-63, 1971-72, 1980-1983, and 1997-1998, otherwise 0

terror: dummy variable for conflict between Kurdish separatist and Turkey This dummy takes a value of one if there are more than 50 incidents and otherwise zero .

elec: dummy variable for the election years. This dummy takes a value of one on the election years and otherwise zero.

All financial data converted constant 1987 prices and growth rate of variables are used to avoid unit root problem.

Table 1: Dependent Variable Defence Expenditure The estimation sample is: 1958 to 2008

\begin{tabular}{|c|c|c|c|}
\hline & Coefficient & t statistics & probobality \\
\hline cons & -0.115 & $-1.84^{*}$ & 0.07 \\
\hline me_1 & -0.249 & $-1.84^{*}$ & 0.07 \\
\hline pop & 6.020 & $3,035^{\star \star \star}$ & 0,00 \\
\hline$y$ & -0.088 & -0.448 & 0.65 \\
\hline Сур & 0.421 & $5.60^{\star \star *}$ & 0,00 \\
\hline terror & 0.123 & $3.24^{* * *}$ & 0,00 \\
\hline coup & 0.105 & $2.41^{* \star}$ & 0.02 \\
\hline elect & 0.008 & 0.293 & 0.77 \\
\hline $\mathrm{R}^{2}$ & 0,53 & & \\
\hline$F(7,43)$ & $6.876^{* *}$ & & \\
\hline DW & 1,8 & & \\
\hline
\end{tabular}

Table (1) presents empirical results from the estimation of equation (1) using ordinary least squares (OLS) estimation. In this estimation we investigated possible relationship between defence spending and election for the period 1958-2008. Our expectation is that there are systematic relationships between 
defence spending and election times. The results showed that elections are not one of the determinants of Turkish defence spending. Military coup cause positive.

Table 2: Dependent Variable Disaggregate Defence Expenditure The estimation sample is: 1975 to 2008

\begin{tabular}{|c|c|c|c|c|c|c|}
\hline & \multicolumn{2}{|c|}{ Defence Expenditure } & \multicolumn{2}{|c|}{$\begin{array}{c}\text { Non-Equipment Defence } \\
\text { Expenditure }\end{array}$} & \multicolumn{2}{|c|}{$\begin{array}{l}\text { Defence Equipment } \\
\text { Expenditure }\end{array}$} \\
\hline & Coefficient & t statistics & Coefficient & t statistics & Coefficient & t statistics \\
\hline cons & -0.055 & -0.529 & -0.097 & -0.757 & 0.031 & 0.101 \\
\hline$y$ & -0.124 & -0.479 & 0.185 & 0.581 & -0.415 & -0.528 \\
\hline pop & 2.829 & 0.502 & 5.023 & 0.725 & -1.896 & -0.111 \\
\hline сур & 0.369 & $4.20^{* \star *}$ & 0.358 & $3.32^{\star * \star}$ & 0.409 & 1.54 \\
\hline coup & 0.082 & 1.084 & 0.032 & 0.338 & 0.569 & $2.39^{\star *}$ \\
\hline terror & 0.096 & $2.23^{* *}$ & 0.067 & 1.77 & 0.187 & 1.44 \\
\hline elec & -0.008 & -0.199 & -0.003 & -0.07 & -0.072 & -0.534 \\
\hline & $\mathrm{R}^{2}$ & 0.50 & $\mathrm{R}^{2}$ & 0.40 & $\mathrm{R}^{2}$ & 0.31 \\
\hline & DW & 1.88 & DW & 2.09 & DW & 2.12 \\
\hline & $\mathrm{F}$ & $4.601^{* *}$ & $\mathrm{~F}$ & $3.016^{*}$ & $\mathrm{~F}$ & 1.843 \\
\hline
\end{tabular}

${ }^{*}$ means significant at 10 percent level

** means significant at 5 percent level

*** means significant at 1 percent level

In this estimation coefficient of lagged dependant defence variable is statistically significant as expected. lagged dependent variable or in other words, the previous year's economic growth is another explanatory variable for Turkey's defence spending and it reflects inertia. It means that the previous year's defence spending is positively correlated to defence spending. Population variable is positive and significant but economic growth (y) did not give significant results. Dummy variables Cyprus, terror and military coup were statistically significant and positively related to defence expenditure. The last 
variable in this estimation is election. The coefficient of election is insignificant. It implies that there is no political business cycles on defence spending. Turning to test statistics, Diagnostic test results are acceptable. R2 is 0.53 and DW tests is 1.80 . and R2 are acceptable. The findings of our analysis are consistent with existing studies.

Table (2) presents empirical results from the estimation of equation (1, 2 and 3 ) using ordinary least squares (OLS) estimation. In this estimation we used disaggregated data on defence spending which are available after 1975. NATO publish disaggregated data for NATO countries as equipment, non-equipment defence expenditure. We re-estimate the models using disaggregated data for the period 1975-2008 as dependant variable. The only significant results is Cyprus dummy in estimation 2 and it is positive. It implies non-equipment defence expenditure determined by Cyprus war. Elections showed insignificant results. Estimation with equipment defence expenditure gave similar results, but military coup cause an increase on Turkish defence spending. Again there is no sign of political business cycles. Finally, the evidence showed that there is no sign of political business cycles on Turkish defence spending.

\section{6- CONCLUSIONS}

Having a big army and important member of NATO, Turkey has frequently attracted by researcher in the subject of defence. Most of these studies focus on security and economic determinants of defence spending and politic aspect of defence spending mainly neglected. Therefore, this study focus on relationship between total defence spending and political business cycle in Turkey for 19582008 and disaggregate defence spending namely equipment and nonequipment, and political business cycle for period of 1975-2008. The empirical findings indicate that there is no significant relationship between total and disaggregate defence spending and political business cycle. This means defence spending is probably not used on a systematic basis by incumbent government to winning election. In other words, Turkish defence spending would not manipulated by politicians.

Additionally, our finding indicate that military coup cause increase both total and non-equipmant of defence expenditure in Turkey. Furthermore same result can be seen for Cyrprus war. As it is expected increasing terror incidents pozitif relation defence expenditure.

Although our study did not find any relation between defence spending and electoral cycle in Turkey, this relation might be more complicated than what we analys. Therefore, future researcher should look different variable such as defence contract, international relations etc. and PBC relations. 


\section{REFERENCES}

Abdel-Rahman, A-M.M. (1997): "The Partisan Theory and Macroeconomic Policy Under Unscheduled Regime Transfers: A Case Study of an LDC", Journal of Economics Studies, 24(4): 222-241.

Akcoraoglu, A. and Yurdakul, F. (2004): "Siyasal Ekonomi Acismdan Buytime, Enflasyon ve Bütce Acikları: Tiirkiye Uzerine Bir Uygulama", Siyasal Bilgiler Fakültesi Dergisi, 59(1),

Akgün, B. (2000): "Explaining the Turkish Vote: Partisanship, İdeology and Economic Factors in Electoral Choice", Unpublished Phd Thesis, Case Western Reserve University, USA.

Alesina, A. Roubini, N. and Cohen G. (1991): "Macroeconomic Policy and Elections in OECD Democracies" NBER Working Paper Series, 3830.

Alesina, A. Roubini, N. and Cohen G. (1991): Political Cycles and the Macroeconomy. Cambridge: USA, MIT pres.

Alesina, A. and Sachs J. (1988) "Political Parties and the Business Cycle in the United States, 1948-1984", Journal of Money, Credit and Banking, 20(1): 6382.

Andrikopoulos, A. Loizides, I. and Prodromidis, K. (2004): "Fiscal Policy and Political Business Cycles in the EU" European Journal of Political Economy, 20: 25-152.

Block, S. A. (2002): " Political Business Cycles, Democratization and Economic Reform: The Case of Africa", Journal of Development Economics, 67: 205-228.

Bravo, A. B. Santos and Silvestre, A. L. "Fiscal Sustaninability, Electoral Cycles and The European Constraint", www.iseg.utl.pt/departamentos/economia/acosemiii/00 Q1/ (12.10.2007)

Brauer, J. (2002): "Survey and review of the defence economics literature on Greece and Turkey: What have we learned?", Defence and Peace economics, 13(2): 85-108.

Derin, I. (2002): "Do Political Business Cycles Exist in Turkey?" Unpublished Phd. Thesis, Faculty of Claremont Graduate University, California, USA.

Derouen, K. and U.K. Heo (2000): "Defense Contracting and Domestic Politics" Political Research Quaterly, 53(4): 753-769.

Dodd, C.H. (1992): “The Development of Turkish Democracy”, British Journal of Middle Eastern Studies, 19(1):16-30. 
Ellis, C. and. Thoma, M. A. (1995): "The Implications for an Open Economy of Partisan Political Business Cycles: Theory and Evidence", European Journal of Political Economy, 11:635-651.

Eren, E. (1988): "Siyasal Konjonktürel Dalgalanmalar ve Türkiye", Uludag Universitesi Iktisadi ve idari BilimlerFakultesi Dergisi, 1(2): .41-52.

Ertuğrul, A. and Selçuk, F. A Brief Account of Turkish Economy, 1980-2000, www.econturk.org/fselçuk.pdf (05.06.2009)

Global Terrorism Data (GTD), Start, University of Maryland, http://www.start.umd.edu/start/data (09.09.2009)

Golden, D. G. and Poterba, J. M. (1980): "The Price of Popularity: The Business Cycle Re-examined", American Journal of Political Science, 24(4): 696-714.

Hallerberg, M., Souza, L. V. and Clark, W. R. (2004): "The Political Business Cycle of EU Accession Countries", European Union Politics 3(2): 235- 2004.

Kalaycıoğlu, E. (1997): "The Logic of Contemporary Turkish Politics", Middle East Review of International Affairs, 3.

Karagöl E. and Turhan, A. (2008): "External Debt, Defence Expenditures and Political Business Cycles in Turkey”, Defence and Peace Economics, 19(3): 217-224.

Kollias, C. and Paleologou, S. M. (2003): "Domestic Political and External Security Determinants of the Demand for Greek Military Expenditure", Defence and Peace Economics, 14(6): 437-445.

Leertouwer, E. and Maier, P. (2002): "International and Domestic Constraints on Political Business Cycles in OECD Economies: A comment", International Organization, 56: 209-221.

Mardin, Ş. (1986): "Türk Siyasasını Açıklayabilecek Bir Anahtar: Merkez-Çevre Illişkileri”, Ersin Kalaycıoğlu ve A.Yaşar Sarıbay (ed.) Türk Siyasal Hayatının Gelişimi. İstanbul: Beta Basım Yayım Dağıım A.Ş.

NATO Review (Various issues)

Paldam, M. (1979): "Is There an Election Cycle? A Comparative Study of Natioanal Accounts", 81: 323-342.

Paldam, M. (1983): "Industrial Conflicts and Economic Condition- A Comparative Emperical Investigation", European Economic Review, 20:: 231256. 
Persson, T. and Tabellini G. (1990): Macroeconomic Policy, Credibility and Politics. Newyork, Harwood Academic Publishers.

Richard, D. J. (1986): "Unanticipated Money and Political Business Cycle", Journal of Money, Credit and Banking, 18(4): 447-457.

Rogoff, K. and Sibert, A. (1988): "Election and Macroeconomic Policy Cycles", The Review of Economic Studies, 55(1): 1-16.

Rogoff, K. (1990): "Equilibrium Political Budget Cycles", The American Economic Review, 80(1):21-36.

Schultz K. A. (1995): "The Politics of the Political Business Cycle", British Journal of Political Science, 25(1): 79-99.

Sezgin, S. (1997): "Country survey X: Defence spending in Turkey", Defence and Peace Economics, 8(4): 381 - 409.

Sezgin, S and Yıldırım J. (2002): "Demand for Turkish Defence Expenditure", Defence and Peace Economics, 13(2): 121-128

SIPRI (Various Years) (Stockholm International Peace Research Institute), www.sıprı.org (03.09.2009)

Soh, B. H. (1986): "Political Business Cycles in industrialized

Democratic Countries", KYKLOS , 39(1): 31-46.

Spanakos, T. (2001): "Political Business Cycles in the Emerging Markets: The Case of Brazil", Conference on Latin American Studies Association.

Tessler, M. and Altınoğlu E. (2004): "Political Culture in Turkey: Connections Among Attitudes Toward Democracy, the Military and Islam" Democratization, 11: 21-50.

Thames, F. C. (2001): "Did Yeltsin Buy Elections? The Russian Political Business Cycle, 1993-1999", Communist and Post-Communist Studies, 34: 6376.

Treisman, D. and Gimpelson V. (2001): "Political Business Cycless and Russian Elections or the Manipulations of "chudar"'", British Journal of Political Science, 31: 225-46.

Turkish Statistical Institute (TURKSTAT), (Various year) Social and Economic Indicators, www.turkstat.gov.tr (03.10.2009) 
Vaubel, R. (1997): "The Bureaucratic and Partisan behavior of independent Central Banks: German and international Evidence", European Journal of Political Economy, 13: 201-224.

Veiga, L. G. (2002): "Political Business Cycles in Local Public Finance", www.eeg.uminho.pt/economia (09.12.2008)

Zuk, G. and Woodbury, N. R. (1986): "U.S. Defense Spending, Electoral Cycles, and Soviet-American Relations", The Journal of Conflict Resolution, 30(3): 445468. 